\title{
Regional travel times to services of general interest in the EU15
}

Working paper $02 / 22$

February 2022

Jeroen Royer, Sanne Velthuis, Mehdi Le PetitGuerin, Rachel Franklin, Tim Leibert, Nicolas Cauchi-Duval, Danny MacKinnon, Andy Pike 


\section{Acknowledgements}

This working paper is an output from the project "Beyond 'Left Behind Places': Understanding Demographic and Socio-economic Change in Peripheral Regions in France, Germany and the UK" (grant reference ES/V013696/1), funded by the Economic and Social Research Council (ESRC), L'Agence Nationale de la Recherche (ANR), and the Deutsche Forschungsgemeinschaft (DFG). We are grateful to the funders for their support.

Centre for Urban and Regional Development Studies (CURDS)

Newcastle University

Newcastle upon Tyne, NE1 7RU

United Kingdom

https://research.ncl.ac.uk/beyondleftbehindplaces/

@PeripheralPlace

To cite this paper:

Royer, J., Velthuis, S., Le Petit-Guerin, M., Franklin, R., Leibert, T., Cauchi-Duval, N., MacKinnon, D., Pike, A. (2022) Regional travel times to services of general interest in the EU15. Beyond Left Behind Places Project Working Paper 02/22. Centre for Urban and Regional Development Studies (CURDS), Newcastle University, UK. DOI: xxxxxxxxxxxxx 


\title{
Regional travel times to services of general interest in the EU15.
}

\author{
Jeroen Royer*, Sanne Velthuis ${ }^{* *}$, Mehdi Le Petit-Guerin***, Rachel Franklin ${ }^{* *}$, Tim Leibert*, \\ Nicolas Cauchi-Duval ${ }^{* *}$, Danny MacKinnon**, Andy Pike** \\ * Leibniz-Institut für Länderkunde \\ ** Centre for Urban and Regional Development Studies (CURDS), Newcastle University \\ *** Sociétés, Acteurs, Gouvernement en Europe (SAGE), Université de Strasbourg
}

\begin{abstract}
In the context of debates about (inner-)peripheries, peripheralization and suspended regions, access to service infrastructure and provision is an important aspect that can cause further reduction of the potential of a region. Therefore, it is important to have an indicator for service accessibility that is comparable across different NUTS3 regions regardless of the size or location of the region. In this working paper, we propose to use the population weighted median travel time to the nearest service as indicator. We construct such population weighted median travel times for a number of services of general interest including shops, pharmacies, and schools, based on data from the ESPON PROFECY project. Additionally, we look at how the travel times to different services are correlated with each other at NUTS3 level and how they correlate to population density and to the urban-rural typology of Eurostat.
\end{abstract}

\section{Introduction}

Processes of peripheralization operate across different scales, affecting regions, subregions, settlements, neighbourhoods and individuals. One of the aspect of peripheralization is a decoupling from innovation and economic networks and from social infrastructure (Kühn \& Weck, 2013). However, other aspects of peripheralization such as age-selective migration and weak labour markets can reduce the economic potential of a region and therefore induce policies and/or private investment decisions that strengthen the process of decoupling and disintegration of social infrastructures and services (Tagai et al.,2018, Barlösius \& Neu 2008), resulting in further selective migration. This is a vicious circle and is combined with the downgrading of one region relative to others (Kühn, 2015; Barlösius \& Neu 2008). Additionally, concepts related with peripheries and peripheralization such as "suspended regions" (abgehängte Regionen) or inner peripheries refer respectively to issues of infrastructural problems or weak infrastructural development (Oberst et al., 2019) and their disconnection to external territories and networks (Noguera et al., 2017; Davies and Michie, 2011). Furthermore, partly resulting from the austerity measures and financial cuts following the 2008 financial crisis, social and care services have changed relevantly over the last decades (Martinelli, 2017b). Most social and care services have undergone horizontal and vertical reorganisation, meaning privatisation and decentralisation of services in ways that may particularly affect poorer people, and which may be heightened by territorial 
differentiation and fragmentation due to differences in available public funding by the local authority (Martinelli,2017b). The privatisation of public services is also visible in mobility, contracting public transport to private companies, which is not always perceived by the population as adequate replacement (Nikolaeva et al., 2019).

The ESPON PROFECY project specifically talks about how good access to services is an important factor contributing to quality of life in a region, and how poor access to services "results in low quality of life and may eventually be the reason to constitute an inner periphery" (Noguera et al., 2017 p. 17). Based on the analysis carried out in this project, inner peripheries with poor access to services of general interest are defined by the authors as follows:

"All areas in Europe that have poor access to five or more services-of-generalinterest, whatever the type of service is, which at the same time have poor access to hospitals (=health care) or poor access to primary schools (=basic education) or poor access to train stations (=basic provision of public transport), are considered an inner periphery." (Schürmann et al, 2017c, p. 98).

As illustrated in the definition above, there are different types of services such as provision of public transport, basic education and health care. However, delimiting services is not easy, there are different definitions encompassing a broad or a narrow range of included services. In the broad definition adopted according to Martinelli (2017a), social services include a variety of services provided to support the welfare and the social inclusion of people, and additionally services for leisure and sport, education, housing and health care. In this paper, services will be defined as services of general interest (SGI) encompassing variety of services provided to support the welfare and the quality of life, including retail facilities, services for leisure, education and health care.

The aim of this working paper is to find an indicator for accessibility to SGI at the NUTS3 level that is comparable with other regions regarding the size or location of the region and link this data to the debates regarding peripheralization and (inner) peripheral regions. Most literature regarding these topics references a loss of services or a growing disconnection from infrastructure and services (Noguera et al., 2017; Kühn \& Weck, 2013; Fischer-Tahir \& Naumann 2013). Since there is a lack of data regarding change over time in the accessibility of services, which would capture this concept best, different variables describing the access to SGI at one point in time are used. Although current technological developments make many services available online, the focus lies on physical access to services since these are access points for the whole population and do not exclude certain groups with no capacity to use online services. Additionally, the data refers to 2016, before the COVID-19 pandemic which might have induced an acceleration of the technological advancements in service 
provision. The data will be generalised from a grid level to NUTS3 regions. This is based on a population weighted median for every NUTS3 region in the EU15 ${ }^{1}$.

\section{Data}

\section{Travel time data}

The data regarding the travel times to SGI is generated by Schürman et al. (2017b) in the context of the ESPON PROFECY project researching inner peripherality.

The travel times are provided by ESPON in a grid with a resolution of $2.5 \mathrm{~km}$. They refer to journey times by car, and are based on the road network from OpenStreetMap (OSM) (2016). OSM is a collaborative project that provides worldwide geographic data. This has many advantages such as a large spatial coverage, many different features such as manmade or natural geographical objects, high spatial resolution, up-to-date with recent changes, open-content license. However, there are also some drawbacks, namely quality assurance, missing detailed information, spatial representation of objects, multiple entries, miscoding and errors, non-standardised names and unclear standards for classification. More information regarding the advantages and disadvantages of OSM are documented by Schürmann et al. (2017a).

Within the ESPON PROFECY project, 'Services of General Interest' (SGI) are defined as cinemas, employment, train stations, shops, doctors, hospitals, pharmacies and schools. Except for doctors, hospitals, primary and secondary schools, cross border services are taken into account (Schürmann et. al, 2017b).

Furthermore, the source dataset contains data for most of Europe but only data for the EU15 is used in this paper. Due to problems with data coverage regarding doctors, certain countries are excluded from further analysis within the ESPON PROFECY project. Most of these are outside EU15, except Greece and Finland (Schürmann et. al, 2017b). Therefore, the dataset regarding travel times towards doctors is not considered in this analysis. Additionally, for the 'service' employment the ESPON PROFECY project uses a proxy, since data regarding the actual location of employment is lacking. Schürmann et. al, (2017b) approached employment by using Urban Morphological Zones (UMZ), but since this is not a very straightforward concept, this service is also excluded from this analysis.

The car travel times to the nearest SGI are given in minutes. Table 1 contains a summary of the data sources used to calculate the car travel times to the nearest service. It only includes the SGI used in this analysis. The coordinate reference system of the data is Lambert Conformal Conic.

\footnotetext{
${ }^{1}$ Austria, Belgium, Denmark, Finland, France, Germany, Greece, Ireland, Italy, Luxemburg, the Netherlands, Spain, Sweden, Portugal and the United Kingdom
} 
Table 1: Original data sources and remarks

\begin{tabular}{|l|l|}
\hline SGI & Definition and data information \\
\hline Cinema & $\begin{array}{l}\text { The data regarding the presence of cinemas comes from OSM } \\
\text { (Schürmann et. al, 2017b). }\end{array}$ \\
\hline Stations & $\begin{array}{l}\text { All passenger train stations are used. The data comes from RRG GIS } \\
\text { Database (Schürmann et. al, 2017b). }\end{array}$ \\
\hline Shops & $\begin{array}{l}\text { The category shops include both supermarkets and convenience stores. } \\
\text { Data on shopping centres and malls have not been compiled, since these } \\
\text { facilities typically are not used for daily goods supply but for medium to } \\
\text { long-run goods. If supermarkets or convenience stores are located inside } \\
\text { such centres or malls, they shall be included in OSM } \\
\text { anyway (Schürmann et. al, 2017a). }\end{array}$ \\
\hline Banks & $\begin{array}{l}\text { Only bank offices are taken into account, locations of individual cash } \\
\text { machines are not (Schürmann et. al, 2017b). }\end{array}$ \\
\hline Pharmacies & $\begin{array}{l}\text { Data comes from OSM plus additional data sources for Germany for } \\
\text { verification (Schürmann et. al, 2017a). }\end{array}$ \\
\hline Hospitals & $\begin{array}{l}\text { In this category, only general hospitals are taken into account. Specialized } \\
\text { facilities such as wellness clinics, hospices, etc. were excluded. The data } \\
\text { comes from OSM, plus additional data sources for verification for Finland, } \\
\text { Germany and Spain (Schürmann et. al, 2017a). Car travel times for this } \\
\text { service only take into account domestic hospitals and not across } \\
\text { international borders (Schürmann et. al, 2017b). }\end{array}$ \\
\hline Primary \\
schools & $\begin{array}{l}\text { The data regarding schools contain primary and secondary schools. In fact, } \\
\text { primary schools and secondary schools were treated as two separate SGls. } \\
\text { Other types of schools such as vocational schools and other training } \\
\text { centres, and tertiary schools are excluded. The data comes from } \\
\text { OSM, OpenEducation Europe, Enicnaric.net, EuroEducation.net (used to } \\
\text { differentiate between primary and secondary school types), plus additional } \\
\text { data sources for verification for Germany and Spain (Schürmann et. al, } \\
\text { 2017a). Car travel times for this service only take into account domestic } \\
\text { schools and not across international borders (Schürmann et. al, 2017b) }\end{array}$ \\
\hline Secondary
\end{tabular}

Sources: Schürmann et al., 2017a, Schürmann et al., 2017b

\section{Population data}

To create population weighted median travel times for each NUTS3 region, we use the population dataset JRC-GEOSTAT 2018. This dataset contains the number of residents for the year $2018^{2}$ for Europe in a regular grid with a resolution of $1 \mathrm{~km}$. Development of the dataset was carried out by the European Commission Joint Research Centre in collaboration

\footnotetext{
2 The population refers to $31 / 12 / 2017$ or $01 / 01 / 2018$. However, this is depending on data availability: for Austria and Sweden (31/12/2018 or 01/01/2019), UK (30/06/2018) and Ireland (24/06/2016). There are more exceptions, however these are out of scope of the study area of the working paper.
} 
with Eurostat, as a follow up of the earlier GEOSTAT editions 2006 and 2011 from Eurostat (Batista e Silva et al; 2021). The grid data has ETRS89 / LAEA as coordinate reference system.

\section{Nomenclature of Territorial Units for Statistics (NUTS) 2016 - Statistical Units}

The dataset 'Nomenclature of Territorial Units for Statistics (NUTS) 2016 - Statistical Units Data set' is used for the delineation of 2016 NUTS3 regions. The dataset is created by the European Commission, Eurostat (ESTAT) and GISCO. The dataset is available in the coordinate reference system ETRS89 / LAEA.

\section{Methodology}

\section{Generalisation to NUTS3}

The original ESPON car travel times are calculated for a grid covering Europe with a grid cell size of 2.5 by $2.5 \mathrm{~km}$. To create representative travel times at NUTS3 level, we calculate a population weighted median per NUTS3 region. Firstly, the ESPON dataset is projected to ETRS89-extended / LAEA Europe (EPSG:3035) to correspond with the NUTS3 delineation and the JRC-Geostat population grid dataset.

Secondly, the JRC-Geostat population grid is used to estimate the population living in each of the ESPON grid cells. The population numbers are calculated based on the assumption that the population is evenly distributed in the grid cells. However, due to different resolution of the two gridded datasets, the borders of the grid cells do not coincide. Therefore, the population numbers are estimated as the sum of the population numbers of all JRC-Geostat grid cells overlapping the ESPON cell scaled to the percentage of overlap with the ESPON grid cell. The population in each ESPON grid cell is estimated with the following formula:

$$
\text { pop }_{\text {espon }}=\sum\left(\text { pop }_{j r c} * \frac{\text { area }_{\text {jrcnespon }}}{\text { area }_{\text {jrc }}}\right)
$$

Finally, since the original data contains a reference to the NUTS 2010/2013 classification rather than the 2016 NUTS classification (which is our preferred version), an intersect between the grid and the 2016 version of NUTS3 polygons is carried out. Subsequently the data is aggregated based on the NUTS3 ID. Then the weighted median is calculated of all grid cells that intersect the NUTS3 region with the estimated population data as weights.

By using population weighted median travel times as indicator for travel times at NUTS3 level, these travel times are comparable across regions. First of all, the median is chosen over the mean as it is more robust to outliers. Secondly, it is weighted with local population data, to ensure only populated areas within the regions are taken into account. A high travel time to a service does not mean a lot when it is in an unpopulated area. By using the population weights, we look at the accessibility to services of the people living in the region and not only to regions with high travel times due to large, very sparsely populated areas and regions with a more mountainous topography. 
By integrating the population as a weight in the measure, the effect of the varieties in area and population of NUTS3 regions is reduced. In addition, the regional median travel times indirectly tell more about the travel times for a large part of the population in this region. To be more concrete, half of the population will have a travel time equal to or lower than the median travel time to the nearest service of interest.

Overseas territories of France, Spain (the Canary Islands) and Portugal (Autonomous region of the Azores and Autonomous region of Madeira) are not considered in this analysis. These overseas territories have a specific legal framework, namely Europe's outermost regions because of their remoteness, small size, difficult terrain and climate, the narrowness of their internal market and their dependence on a small number of products (Kołodziejski, 2021). In addition, the Spanish African territories (Ceuta and Melilla) are also excluded due to their small size and isolated location. Furthermore, for some of these regions, the source data (location of the different SGI) was not gathered or unavailable, and travel times were either not calculated or calculated to the nearest service on either the mainland or another Island. Therefore, these regions are not considered in the analysis.

\section{Correlation analysis}

A Pearson correlation analysis is carried out to estimate the correlation between travel times to the different services. This to see if there are similarities in the travel times to the different services at NUTS3 level. If the absolute value of the Pearson correlation coefficient is close to 1 , there is a high correlation between the travel times to the different services in a region. The plus or minus sign indicates in which direction the correlation is.

Additionally, a Spearman rank correlation analysis is carried out to find the correlation between the travel times to the different services. This to check for similarities in the distribution of the travel times to the different services at NUTS3 level. If the absolute value of the Spearman correlation coefficient is close to 1 there is a high correlation between the order of the different regions for the travel times to the different services. The plus or minus sign respectively refer to a positive or a negative correlation.

\section{Results}

\section{Generalisation to NUTS3 level}

Figure 1 (a-h) illustrates the car travel times to, respectively, bank offices, supermarkets and convenience stores, pharmacies, hospitals, primary schools, secondary schools, passenger train stations, and cinemas.

A first observation is that the car travel times vary a lot depending on the service. For some services car travel times are characterised by a greater range compared to others, e.g. for cinemas travel times range from 0 to more than 25 minutes but for supermarkets and convenience stores and primary schools from 0 to 6 minutes for 95 percent of the NUTS regions. This means that accessibility to supermarkets and convenience stores and primary schools is relatively even across regions with most regions having fairly good access to 
supermarkets and convenience stores, but accessibility of cinemas is more variable with some regions (e.g. big cities) having good accessibility but other regions much less good accessibility. Furthermore, there are similar spatial patterns for all services. Car travel times are generally shorter in regions in North-Western Germany, Northern Belgium, the Netherlands, in Ireland around Dublin, Central and Southern England, and longer in regions in Central Spain, East Portugal, Southern Italy, South of Belgium, East Germany and Northern and Western Ireland. However, some services show stronger spatial similarities like hospitals and primary schools, supermarkets and convenience stores and primary schools, banks and pharmacies, banks and supermarkets and convenience stores etc. The services secondary schools, stations and cinemas show fewer spatial similarities.

Additionally, the car travel times show some national differences. For example, Greece has in general higher median car travel times. Also, Sweden and Finland have longer car travel times except for primary schools and supermarkets and convenience stores. Even within the countries there are clear differences observable. In France, the North-West and the SouthEast also show longer car travel times to all services. In addition, Central Spain and East Portugal also show longer car travel times compared to the other regions of the country.

\section{Correlation analysis}

In the next step, a correlation analysis for the different car travel times is carried out. The results can be found below in Table 2. There is a strong correlation between the car travel time to banks, primary schools, supermarkets and convenience stores, and pharmacies, with a slightly less strong correlation with hospitals. On the other hand, car travel times to secondary schools, stations and cinemas show little correlation with the other SGI. This means that the services banks, supermarkets and convenience stores, primary schools, pharmacies, and to certain extent hospitals, have similarities in their distribution, meaning that if the car travel time to the nearest bank is long it would most likely be long for the services supermarkets and convenience stores, pharmacies, primary schools and hospitals. However, it will not indicate anything about the travel times to primary schools, cinemas or train stations.

Since the Pearson correlation coefficient tells more on how the data correlates, the Spearman rank coefficient tells something more about the position (rank) of a region compared to the other regions. With high correlation coefficients this means the order of the regions based on the travel times to certain services are similar. Table 5 shows the Spearman rank correlation coefficient between the travel times to the different services. These correlation coefficients are all high, meaning that regions that rank low in terms of car travel times to banks will also rank low in terms of car travel times to the other services. In other words, there are places with a high density in services and with low density in services. The strongest correlation is visible between car travel times to primary schools and to supermarkets and convenience stores and between the car travel times to supermarkets and convenience stores and pharmacies. The weakest correlation is visible between car travel times to stations and to hospitals and car travel times to banks and to hospitals. 
Figure 1: Population weighted median car travel times to SGI in the EU15

a. Banks

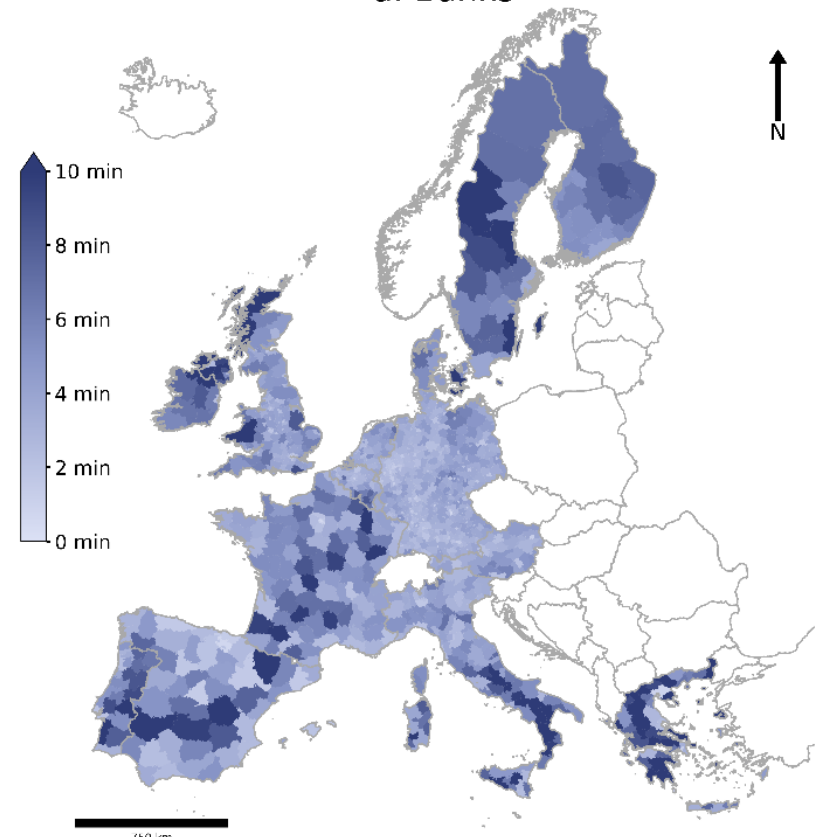

c. Pharmacies

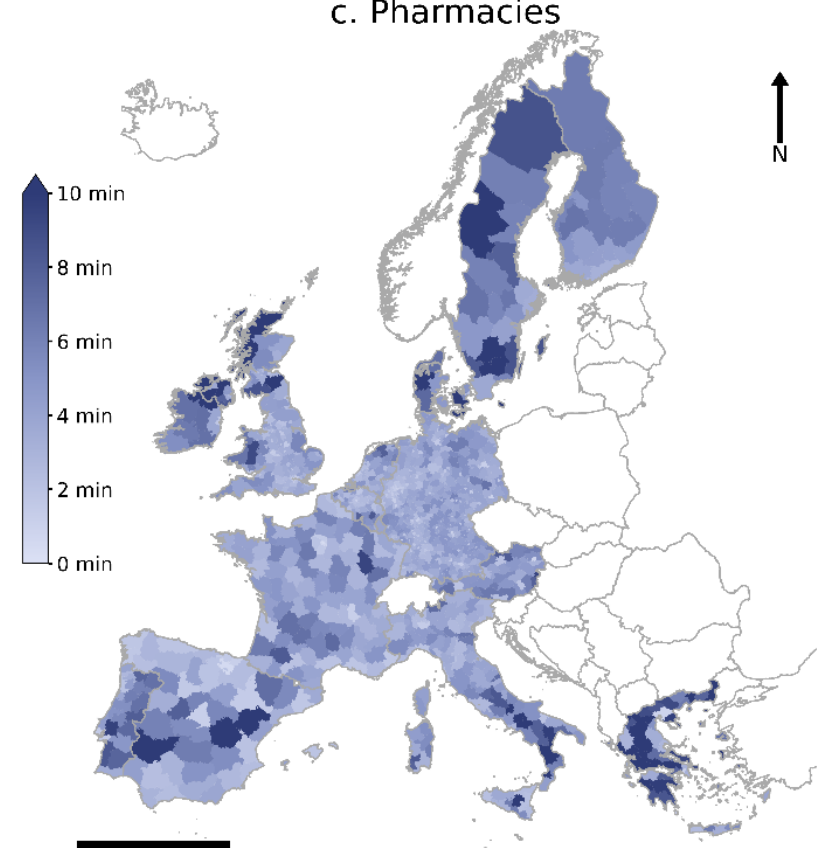

b. Supermarkets and convenience stores

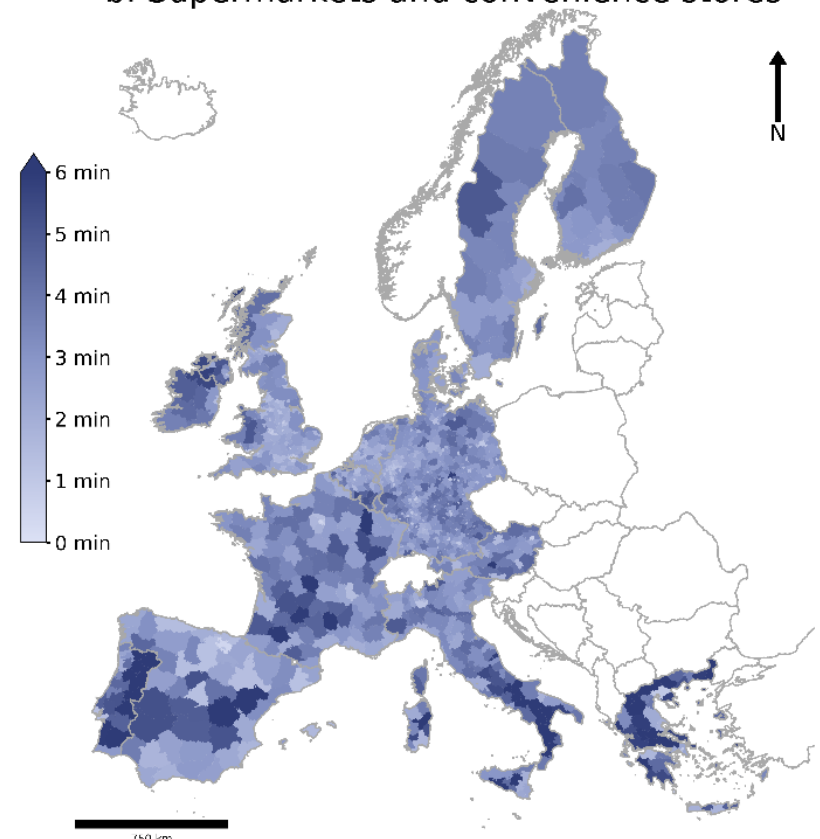

d. Hospitals

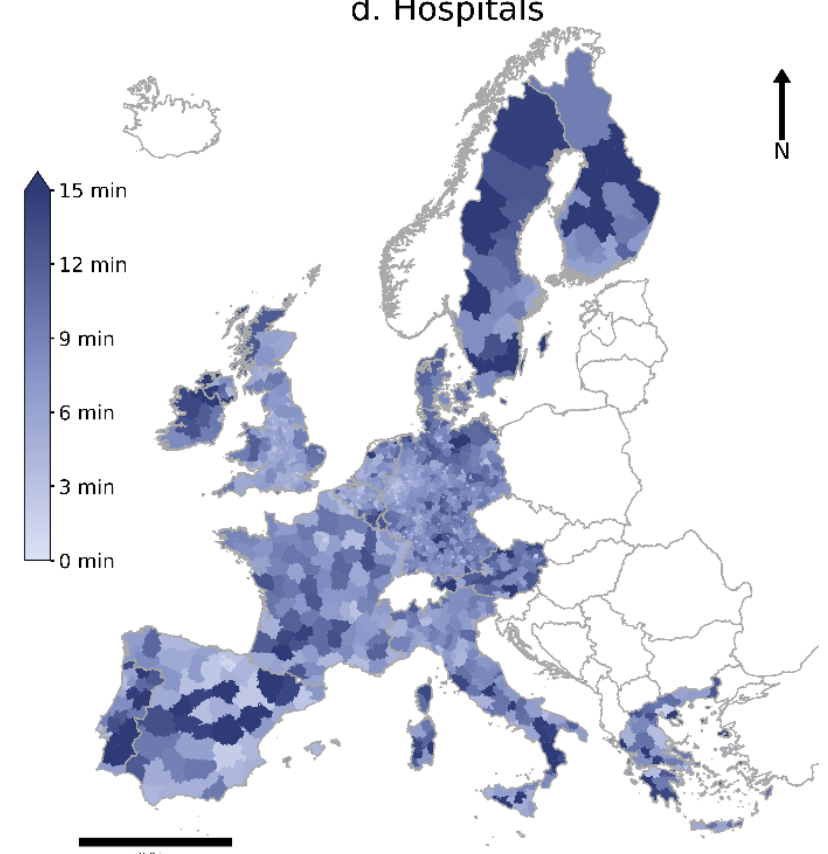



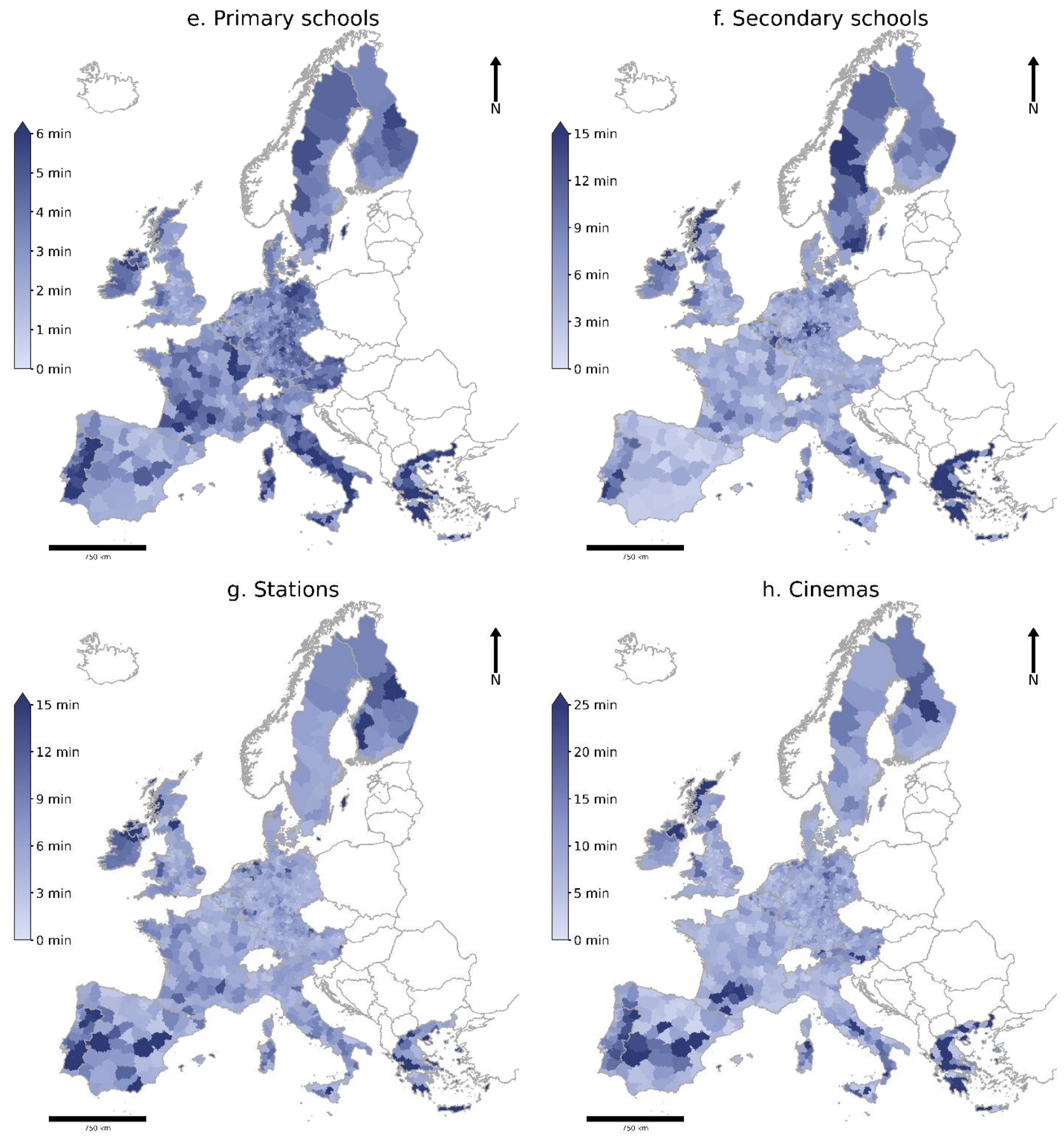

Sources: Administrative boundaries: ( ) EuroGeographics; Data: () ESPON 2020; Note: the maximum car travel time indicated on the maps legends correspond more or less with the $95^{\text {th }}$ percentile, meaning that 5 percent of the regions have median car travel times to the nearest service longer than this maximum value.

Disclaimer: The interpretation of ESPON material does not necessarily reflect the opinion of the ESPON 2020 Monitoring Committee. 
Table 2: Pearson correlation analysis on median car travel time data (coloured cells have a correlation coefficient greater than 0.70 )

\begin{tabular}{|c|c|c|c|c|c|c|c|c|}
\hline & Banks & $\begin{array}{c}\text { Supermarkets } \\
\text { and } \\
\text { convenience } \\
\text { stores }\end{array}$ & $\begin{array}{c}\text { Primary } \\
\text { schools }\end{array}$ & $\begin{array}{c}\text { Secondary } \\
\text { schools }\end{array}$ & Pharmacies & Hospitals & Stations & Cinemas \\
\hline Banks & 1.00 & 0.74 & 0.71 & 0.15 & 0.75 & 0.60 & 0.18 & 0.21 \\
\hline $\begin{array}{c}\text { Supermarkets } \\
\text { and } \\
\text { convenience } \\
\text { stores }\end{array}$ & 0.74 & 1.00 & 0.88 & 0.14 & 0.71 & 0.71 & 0.09 & 0.18 \\
\hline $\begin{array}{c}\text { Primary } \\
\text { schools }\end{array}$ & 0.71 & 0.88 & 1.00 & 0.18 & 0.68 & 0.72 & 0.14 & 0.19 \\
\hline $\begin{array}{c}\text { Secondary } \\
\text { schools }\end{array}$ & 0.15 & 0.14 & 0.18 & 1.00 & 0.14 & 0.16 & 0.37 & 0.28 \\
\hline Pharmacies & 0.75 & 0.71 & 0.68 & 0.14 & 1.00 & 0.57 & 0.15 & 0.30 \\
\hline Hospitals & 0.60 & 0.71 & 0.72 & 0.16 & 0.57 & 1.00 & 0.11 & 0.14 \\
\hline Stations & 0.18 & 0.09 & 0.14 & 0.37 & 0.15 & 0.11 & 1.00 & 0.43 \\
\hline Cinemas & 0.21 & 0.18 & 0.19 & 0.28 & 0.30 & 0.14 & 0.43 & 1.00 \\
\hline
\end{tabular}

Source: () ESPON 2020, Origin of data: ESPON EGTC, Disclaimer: The interpretation of ESPON material does not necessarily reflect the opinion of the ESPON 2020 Monitoring Committee.

Table 3: Spearman rank correlation analysis on median car travel time data (coloured cells have a correlation coefficient greater than 0.80 )

\begin{tabular}{|c|c|c|c|c|c|c|c|c|}
\hline & Banks & $\begin{array}{c}\text { Supermarkets } \\
\text { and } \\
\text { convenience } \\
\text { stores }\end{array}$ & $\begin{array}{c}\text { Primary } \\
\text { schools }\end{array}$ & $\begin{array}{c}\text { Secondary } \\
\text { schools }\end{array}$ & Pharmacies & Hospitals & Stations & Cinemas \\
\hline Banks & 1.00 & 0.82 & 0.74 & 0.73 & 0.88 & 0.69 & 0.72 & 0.75 \\
\hline $\begin{array}{c}\text { Supermarkets } \\
\text { and } \\
\text { convenience } \\
\text { stores }\end{array}$ & 0.82 & 1.00 & 0.91 & 0.79 & 0.89 & 0.80 & 0.77 & 0.81 \\
\hline $\begin{array}{c}\text { Primary } \\
\text { schools }\end{array}$ & 0.74 & 0.91 & 1.00 & 0.81 & 0.84 & 0.81 & 0.73 & 0.78 \\
\hline $\begin{array}{c}\text { Secondary } \\
\text { schools }\end{array}$ & 0.73 & 0.79 & 0.81 & 1.00 & 0.79 & 0.74 & 0.72 & 0.74 \\
\hline Pharmacies & 0.88 & 0.89 & 0.84 & 0.79 & 1.00 & 0.78 & 0.76 & 0.81 \\
\hline Hospitals & 0.69 & 0.80 & 0.81 & 0.74 & 0.78 & 1.00 & 0.69 & 0.76 \\
\hline Stations & 0.72 & 0.77 & 0.73 & 0.72 & 0.76 & 0.69 & 1.00 & 0.72 \\
\hline Cinemas & 0.75 & 0.81 & 0.78 & 0.74 & 0.81 & 0.76 & 0.72 & 1.00 \\
\hline
\end{tabular}

Source: (C) ESPON 2020, Origin of data: ESPON EGTC, Disclaimer: The interpretation of ESPON material does not necessarily reflect the opinion of the ESPON 2020 Monitoring Committee. 


\section{Discussion}

As can be seen in a comparison of Figure $1 \mathrm{a}$ to $\mathrm{h}$, similar patterns of population weighted median car travel times can be observed for different services. This argument is also strengthened by the correlation analysis. High Pearson correlation coefficient (close to 1) indicate that there is a similar distribution. For example, regions with high car travel times to banks often have high car travel times to supermarkets and convenience stores and vice versa.

However, not all services are equally strongly correlated in terms of accessibility. For example, median regional car travel times to secondary schools have a less strong correlation with the median car travel times to other services than with the median car travel times to primary schools. This might be because secondary schools are partially co-located, meaning there are some schools offering both primary and secondary education or secondary schools are rather closely located to primary schools. However, there are more primary schools than secondary schools so therefore it is not strongly correlated.

Additionally, regional median car travel times to hospitals show a weaker correlation with the other services. Furthermore, regional median car travel times to stations, secondary schools and cinemas show very little correlation with other services. These services and including hospitals are also the services which are expected to have longer car travel times in general. Additionally, the Spearman rank correlation analysis suggests that the regions rank rather similarly on the car travel times to the different services, meaning that regions with very short car travel times also have shorter car travel times for other services compared to other regions.

The strongest correlation is present between supermarkets and convenience stores and primary schools. In comparison with services like hospitals, cinemas, stations and secondary schools with in general longer car travel times, the accessibility of primary schools, supermarkets or convenience stores is better overall since both SGI have shorter car travel times. Additionally, banks and pharmacies also have rather short travel times. In general, these are services of everyday needs. Poor access to SGI result in a lower quality of life (Noguera et al., 2017). We could even debate that poor access to SGI providing more basic needs, reflects a more severe peripheralized region or stronger periphery than areas with only longer travel times to other types of SGI such as cinemas. It is reassuring that car travel times to shops and primary schools are, on the whole, relatively low compared to other services. However, since these are car travel times, we assume that a journey that takes 6 minutes by car most likely would take longer via public transport, and even more so on foot or by bike. Additionally, there are large national differences. In Greece and Italy, there are respectively 25 and 21 regions with either a car travel time to primary school or to supermarkets of convenience stores over $6 \mathrm{~min}$, while most other countries have only a few regions with similar car travel times to primary schools or supermarkets or convenience stores. 
Most of the regions with longer car travel times are regions with sparser populations, including the southern regions of Belgium, Northern Greece, Northern Sweden, Northern Finland and East Portugal. This is also illustrated by the correlation coefficients in Table 4. An additional correlation analysis is carried out between the car travel time data and population density data ${ }^{3}$ at the level of NUTS3 regions. As can be seen in this table, the correlation between population density and the actual travel times (Pearson correlation coefficient) is rather weak. However, there is a much stronger inverse correlation between the ranking of the regions based on population density and the ranking of the regions based on car travel times to each service. This suggests that regions ranked low on population density tend to rank higher in terms of travel times, as we would expect. More specifically, the accessibility of pharmacies, supermarkets and convenience stores, and primary schools is more closely related to population density than the accessibility of secondary schools, train stations and cinemas. The latter are services that on average have longer car travel times and therefore are serving larger areas. Therefore, the correlation might be less strong, due to a more dispersed spatial pattern. For example, train stations will appear in the countryside if there is a railway line passing by, meaning it will not always occur in areas with larger population density. Secondary schools and hospitals serve in general larger areas in comparison with primary schools. In addition, in less dense areas, there might be more but smaller hospitals or smaller secondary schools in comparison with larger facilities in denser regions. However, in this analysis, the size of the facility is not taken into account.

Table 4: Correlation analysis between car travel times to different services and with population density at NUTS3 level

\begin{tabular}{|l|c|c|}
\hline \multicolumn{1}{|c|}{ Services } & $\begin{array}{c}\text { Pearson } \\
\text { correlation } \\
\text { coefficient }\end{array}$ & $\begin{array}{c}\text { Spearman } \\
\text { rank } \\
\text { correlation } \\
\text { coefficient }\end{array}$ \\
\hline Banks & -0.29 & -0.75 \\
\hline $\begin{array}{l}\text { Supermarkets } \\
\text { and } \\
\text { convenience } \\
\text { stores }\end{array}$ & -0.39 & -0.79 \\
\hline Primary schools & -0.39 & -0.76 \\
\hline $\begin{array}{l}\text { Secondary } \\
\text { schools }\end{array}$ & -0.05 & -0.69 \\
\hline Pharmacies & -0.29 & -0.79 \\
\hline Hospitals & -0.40 & -0.74 \\
\hline Stations & -0.05 & -0.72 \\
\hline Cinemas & -0.07 & -0.73 \\
\hline
\end{tabular}

Source: ARDECO (RNPTN), 2018, ( ) ESPON 2020, Origin of data: ESPON EGTC

\footnotetext{
${ }^{3}$ Population data for the year 2018 comes from the dataset 'Total Population (Demographic Statistics)' in the ARDECO database. The data available on ARDECO are sourced from Eurostat, but are occasionally supplemented by national data sources.
} 
Disclaimer: The interpretation of ESPON material does not necessarily reflect the opinion of the ESPON 2020 Monitoring Committee.

In addition, there are clear national differences in the provision of services. For example, car travel times to banks are in general much lower in Germany and Austria. This largely dependent on technological improvements especially since some services are digitalised and available to access online. For example, mobile and internet banking and the use of cash versus digital payments, change the demand for bank offices.

\section{Comparison with NUTS3 urban - rural typology}

Next, car travel times are compared with the NUTS3 urban-rural typology. The results are summarised in Table 5. On average, predominantly urban regions have shorter car travel times to services than respectively intermediate and predominantly rural regions. If the standard deviation is very large, there are more regional variations and/or missing services (or incomplete data coverage for this service). For instance, it seems that not only car travel times are longer for secondary schools than for primary schools across all three urban-rural categories, the standard deviations are also much larger for secondary schools, suggesting that while most regions have at least a reasonable accessibility of primary schools (even rural regions), there will be some regions in which the car travel time to the nearest secondary school is extremely long.

Table 5: Comparison Urban-Rural classification (NUTS3) and car travel times to SGI.

\begin{tabular}{|c|l|r|r|r|}
\hline \multirow{2}{*}{ SGI $\begin{array}{r}\text { classification } \\
\text { Banks }\end{array}$} & $\begin{array}{l}\text { Predominantly } \\
\text { urban (332) }\end{array}$ & $\begin{array}{l}\text { Intermediate } \\
(440)\end{array}$ & $\begin{array}{l}\text { Predominantly } \\
\text { rural (319) }\end{array}$ \\
\cline { 2 - 5 } & Standard deviation & 3.32 & 4.20 & 6.32 \\
\hline $\begin{array}{c}\text { Supermarkets } \\
\text { and convenience } \\
\text { stores }\end{array}$ & Mean & 8.73 & 2.40 & 3.92 \\
\cline { 2 - 5 } Hospitals & Standard deviation & 1.91 & 2.99 & 4.39 \\
\cline { 2 - 5 } & Mean & 0.75 & 1.12 & 1.95 \\
\cline { 2 - 5 } & Standard deviation & 4.97 & 7.98 & 11.11 \\
\hline \multirow{2}{*}{ Pharmacies } & Mean & 1.85 & 2.89 & 3.93 \\
\cline { 2 - 5 } & Standard deviation & 2.54 & 4.11 & 6.10 \\
\hline \multirow{2}{*}{$\begin{array}{c}\text { Primary schools } \\
\text { Secondary }\end{array}$} & Mean & 1.10 & 3.15 & 3.21 \\
\cline { 2 - 5 } schools & Standard deviation & 1.99 & 3.23 & 4.69 \\
\cline { 2 - 5 } & Mean & 0.74 & 1.30 & 1.79 \\
\hline \multirow{2}{*}{ Stations } & Standard deviation & 3.50 & 9.40 & 18.34 \\
\cline { 2 - 5 } & Standard deviation & 1.53 & 59.88 & 63.89 \\
\hline \multirow{2}{*}{ Cinemas } & Mean & 4.35 & 18.52 & 38.34 \\
\cline { 2 - 5 } & Standard deviation & 8.99 & 120.67 & 171.47 \\
\hline
\end{tabular}

Source: Eurostat. (2018). Note: Following regions are not taken into account: ES640, ES707, ES709, ES706, ES708, ES705, ES704, ES703, PT200, and PT300. (c) ESPON 2020, Origin of data: ESPON EGTC,

Disclaimer: The interpretation of ESPON material does not necessarily reflect the opinion of the ESPON 2020 Monitoring Committee.

Additionally, the higher standard deviation for the car travel times to secondary schools also suggest that there are more variations in the time needed to reach the nearest secondary 
school for intermediate and rural regions. This in turn, resonates with the assumption that there might be more but smaller secondary schools present in some predominantly rural and intermediate areas, but not all. Additionally, shorter car travel times to train stations are more common in predominantly urban and intermediate areas than in rural areas. Additionally, the standard deviation is very large in intermediate and predominantly rural areas, this illustrates the absence of train stations in some of these regions due to topography or remote location for example in mountain ranges or on islands or due to different national transport policies and investments in railway infrastructure. This is similar for cinemas and for secondary schools but to a much lesser extent.

\section{Conclusion}

As mentioned before, most literature regarding peripheralization mention a loss of services or a disconnection from infrastructure and services over time (Noguera et al., 2017; Kühn \& Weck, 2013; Fischer-Tahir \& Naumann 2013). In response, this paper sought to access car travel time to services across EU15 regions. Due to a lack of historical data regarding service provision and the development over time, data for physical access to services at one point in time is used, provided by ESPON. The data is generalised from a grid level to NUTS3 regions. This is done by using a population weighted median for every NUTS3 region in the EU15. The proposed method is used because it makes the car travel times more comparable between different NUTS3 regions regardless of the country, size and population of the region.

Based on the analysis presented above, there is a correlation between the car travel times for the services banks, supermarkets and convenience stores, primary schools, pharmacies and to some lesser extent hospitals. In addition, there is a high correlation in the ranking of regions according to the car travel times to services. The strongest correlation (both Pearson and Spearman) is present between supermarkets and convenience stores and primary schools. Both represent basic needs and therefore good accessibility to these services for daily life is more important. A disconnection or poor accessibility of everyday services, could indicate a more peripheralized area. Moreover, these are all car travel times, this means that people with no access to a car are having a lower access to services when they would travel by foot, public transport or bicycle.

Additionally, there is a correlation between the ranking of regions on population densities and car travel times to services for all services, meaning that regions with shorter car travel times for one service will have also shorter car travel times for another service in comparison with the other regions. Furthermore, as would be expected, NUTS3 regions classified as 'predominantly urban' have on average shorter car travel times to services than regions classified as 'intermediate' or 'predominantly rural'. SGI that serve larger areas, have generally a more spread out pattern, with longer car travel times. However, the population weighted median car travel times for these SGI within the intermediate and predominantly rural region have large variations, showing a variability in service provision in intermediate and predominantly rural areas which could be related to peripheralization processes. 
To conclude, the provision of different types of SGI is correlated to each other and to population density and there are clear differences between different types of regions. More rural and remote regions have longer car travel times than central and urban regions. This means that there is a territorial inequality in service provision which according to Martinelli et al. (2017b) has increased for social and care services since the austerity measures and financial cuts following the 2008 crisis. 


\section{References}

European Commission (2021) Total Population on 1 January (Demographic Statistics), ARDECO online. https://knowledge4policy.ec.europa.eu/territorial/ardeco-online en

Barlösius, E., \& Neu, C. (2008). Territoriale Ungleichheit: Eine spezifische Ausprägung räumlicher Untergleichheit. Zukunftsorientierte Nutzung ländlicher Räume-Land Innovation, 17.

Batista e Silva F, Dijkstra L, Poelman H (2021) The JRC-GEOSTAT 2018 population grid. JRC Technical Report. Forthcoming

Davies, S., \& Michie, R. (2011). Peripheral regions: a marginal concern. European Policies Research Centre Paper, 11(6).

Eurostat. (2018). Methodological Manual on Territorial Typologies -2018 edition.

ESPON (2020) Travel time to the next Service of General Interest point (grid). ESPON EGTC https://database.espon.eu/indicator/876/

Fischer-Tahir A., Naumann M. (2013) Introduction:Peripheralization as the Social Production of Spatial Dependencies and Injustice. In: Fischer-Tahir A., Naumann M. (eds) Peripheralization. Springer VS, Wiesbaden. DOI:10.1007/978-3-531-19018-1 1

Kołodziejski, M. (2021, September 1). Outermost regions (ORs) | Fact sheets on the European Union | European Parliament. European Parliament. Retrieved January 28, 2022, from https://www.europarl.europa.eu/factsheets/en/sheet/100/outermostregions-ors-.

Kühn M., Weck S. (2013) Peripherisierung - ein Erklärungsansatz zur Entstehung von Peripherien. In: Bernt M., Liebmann H. (eds) Peripherisierung, Stigmatisierung, Abhängigkeit?. Springer VS, Wiesbaden. DOI:10.1007/978-3-531-19130-0 2

Manfred Kühn (2015) Peripheralization: Theoretical Concepts Explaining Socio-Spatial Inequalities, European Planning Studies, 23:2, 367-378, DOI: $10.1080 / 09654313.2013 .862518$

Martinelli, F. (2017a). "Social services, welfare states and places: an overview". In Social Services Disrupted. Cheltenham, UK: Edward Elgar Publishing. DOI: $10.4337 / 9781786432117.00009$

Martinelli, F. (2017b). "Social services disrupted: changing supply landscapes, impacts and policy options". In Social Services Disrupted. Cheltenham, UK: Edward Elgar Publishing. DOI: $\underline{10.4337 / 9781786432117.00031}$

Nikolaeva, A., Adey, P., Cresswell, T., Lee, JY., Nóvoa, A., Temenos, C. (2019) Commoning mobility: Towards a new politics of mobility transitions. Transactions of the Institute of British Geographers, 44(2): 346- 360. DOI; 10.1111/tran.12287 
Noguera, j., Ortega-Reig, M., del Alcázar, H., Copus, A., Berlina, A., Moodie, J., Mantino, F., Forcina, B., Weck, S., Beißwenger, S., Hans, N., Tagai, G., Koós, B., Kovács, K., Uzzoli, A., Dax, T., Machold, I., Schürmann, C., Tobiasz-Lis, P., Dmochowska-Dudek, K., Wójcik, M. (2017) PROFECY - Processes, Features and Cycles of Inner Peripheries in Europe. Final Report. ESPON EGTC. https://www.espon.eu/innerperipheries

Oberst, C., Kempermann, H., \& Schröder, C. (2019). Räumliche Entwicklung in Deutschland. In M. Hüther, J. Südekum, \& M. Voigtländer (Eds.), Die Zukunft der Regionen in Deutschland Zwischen Vielfalt und Gleichwertigkeit. (pp 87-114) IW-Studien - Schriften zur Wirtschaftspolitik aus dem Institut der deutschen Wirtschaft, ISBN 978-3-60245621-5, Institut der deutschen Wirtschaft Köln Medien GmbH, Köln.

Schürmann, C.; Ortega-Reig, M.; del Alcázar, H.; Tagai, G. (2017a): PROFECY - Inner Peripheries: National territories facing challenges of access to basic services of general interest. Final Report. Annex 2: Datasets and database. ESPON EGTC. https://www.espon.eu/inner-peripheries

Schürmann, C.; Ortega-Reig, M.; Noguera, J. (2017b): PROFECY - Inner Peripheries: National territories facing challenges of access to basic services of general interest. Abschlussbericht. Annex 4: From conceptualisation to delineation. ESPON EGTC. https://www.espon.eu/inner-peripheries

Schürmann, C (2017c): PROFECY - Inner Peripheries: National territories facing challenges of access to basic services of general interest. Final Report. Annex 7. Delineation 3 Series of Maps illustrating the Delineation Process. ESPON EGTC. https://www.espon.eu/inner-peripheries

Tagai, G., Bernard, J., Šimon, M., \& Koós, B. (2018). Two faces of peripherality: labour markets, poverty, and population dynamics in Hungary and Czechia. Regional Statistics, 8(2), 19-45. 